\author{
Jožica Škofic \\ Znanstvenoraziskovalni center Slovenske akademije znanosti in umetnosti \\ Inštitut za slovenski jezik Frana Ramovša \\ Ljubljana \\ ORCID: 0000-0003-3478-5056; e-mail: jozica.skofic@zrc-sazu.si
}

\title{
Narečna poimenovanja za kmečke posestnike kot motivacija hišnih imen na Gorenjskem
}

\begin{abstract}
Povzetek: V prispevku so predstavljena s poimenovanji za kmečke posestnike motivirana narečna hišna imena na Gorenjskem, zbrana v večletnem projektu Kako se pri vas reče? (2009-2020). Gradivo je primerjano $\mathrm{z}$ narečnimi apelativi, zbranimi $\mathrm{z}$ enotno anketno metodo $\mathrm{v}$ izbranih krajevnih govorih Slovenskega lingvističnega atlasa (SLA), tj. V181 kmet, V185 gruntar in V186 bajtar, kar omogoča primerjalno analizo občnoimenskega in lastnoimenskega narečnega gradiva na vseh jezikovnih ravninah - fonološki, morfološki, leksični (z etimologijo) in sintaktični.
\end{abstract}

Ključne besede: dialektologija, geolingvistika, Slovenski lingvistični atlas (SLA), Gorenjska, mikrotoponimija, hišna imena

\begin{abstract}
Dialect lexemes for peasant landowners as motivation for house names in the Gorenjska/ Upper Carniola region. The article presents dialect house names in the Gorenjska/Upper Carniola region, motivated by names for peasant landowners, collected as part of the project What do you call your house? (2009-2020). The material has been compared with dialect appellatives collected by means of a uniform survey method in selected local dialects within the Slovenian Linguistic Atlas (SLA), i.e. V181 farmer, V185 big farmer and V186 cottager, which enables comparative analysis of dialect appellatives and proper names on all linguistic levels: phonological, morphological, lexical (with etymology) and syntactic.
\end{abstract}

Keywords: dialectology, geolinguistics, Slovenian Linguistic Atlas (SLA), Upper Carniola, microtoponyms, house names.

\section{Uvod}

Lastna imena (osebna, zemljepisna in stvarna) so pomemben del jezika, saj s svojo individualizacijsko, diferenciacijsko in lokalizacijsko vlogo postavljajo poimenovane objekte v miselni in stvarni prostor ljudi, ki poimenujejo svet okoli sebe. Pri raziskovanju (hišnih) imen je treba upoštevati

(1) ime $\mathrm{z}$ vsemi oblikoslovnimi značilnostmi in njegovo družino $\mathrm{v}$ celoti, (2) ustrezno interpretacijo narečnih podatkov, (3) srednjeveške zapise, če so na voljo, sicer pa čim starejše, (4) terenske podatke, zlasti kadar domnevamo izvor v občnem imenu, (5) starejšo 
krajevno zgodovino, če je znana, (6) lokalno imenotvorno tipologijo in (7) primerljivo občno- in lastnoimensko gradivo iz drugih jezikov (Snoj 2009, 8).

Lastna imena, predvsem zemljepisna, kamor uvrščamo tudi hišna imena, so zanimiva tudi za dialektološko raziskovanje, saj so bogata zakladnica informacij o jeziku, njegovem razvoju in zemljepisnih različicah (narečjih), o ljudeh, ki ta jezik in njegove organske, tj. nenormirane, zemljepisne različice govorijo, ter o naravnem in družbenem okolju, v katerem so ta imena nastala in kjer se uporabljajo. Slovenski narečni mikrotoponimi (tudi hišna imena) so pomemben del nacionalne žive kulturne dediščine in so zanimivi tako za različne humanistične, družbene in naravoslovne vede (ob jezikoslovju tudi za geografijo, etnologijo, zgodovino...) kot tudi za nestrokovno javnost. Hišna imena oz. njihova raba so bila leta 2020 kot posebna enota vpisana tudi v nacionalni register nesnovne kulturne dediščine pri Ministrstvu za kulturo Republike Slovenije.

$\mathrm{V}$ tej razpravi ${ }^{1}$ so predstavljena hišna imena, ki so bila sistematično in $\mathrm{z}$ enotno metodo ${ }^{2}$ zbiranja, narečnega zapisovanja in poknjiževanja ter interpretacije poimenovalne motivacije zbrana v projektih Kako se pri vas reče ${ }^{3}$ ? in FLU-LED ${ }^{4}$ - njihov cilj je ohranjati nesnovno kulturno dediščino in obujati rabo narečnih imen v vsakdanjem življenju domačinov.

Hišna imena $\mathrm{v}$ slovenskem jezikoslovju pojmujemo kot poimenovanja najmanjših naselitvenih enot - hiš s pripadajočimi posestmi (zemljo, gospodarskimi poslopji) in njihovimi prebivalci. Hišna imena se redko spreminjajo, čeprav hiše z dedovanjem ali prodajo menjajo lastnika - ohranjajo se $\mathrm{z}$ ustnim posredovanjem iz roda $\mathrm{v}$ rod. Hišna

1 Prispevek je nastal v okviru programa Slovenski jezik v sinhronem in diahronem razvoju (P6-0038, 1. 1. 2004 - 31. 12. 2021), ki ga financira ARRS, in projekta i-SLA: interaktivni atlas slovenskih narečij (L6-2628, 1. 9. 2020 - 31. 8. 2023), ki ga sofinancirata ARRS in SAZU.

${ }^{2}$ Metoda je predstavljena v Klinar, Škofic, Šekli, Piko-Rustia 2012, publikaciji, ki je nastala v okviru projekta FLU-LED.

3 Projekte (z različnimi delovnimi imeni) zbiranja hišnih imen vodi Klemen Klinar iz Razvojne agencije Zgornje Gorenjske (RAGOR) že od leta 2009. Sofinancirani so bili s strani Evropske unije, programa LEADER, delno so jih financirale tudi v projekt vključene gorenjske občine. V raziskavi Kako se pri vas reče? je sodelovalo okrog 1200 domačinov različnih starosti, ki so na terenu posredovali domača, tj. narečna ledinska in hišna imena $\mathrm{v}$ različnih slovničnih oblikah (imenovalnik, rodilnik, mestnik, orodnik), skupaj z izpeljankami za pridevnik, lastnika in lastnico, ter jih z zapisovalcem umestili na zemljevid. Imena so bila na terenu posneta in zapisana $\mathrm{v}$ poenostavljeni narečni transkripciji, $\mathrm{v}$ sodelovanju $\mathrm{z}$ dialektologi je bil zapis ponovno pregledan in dopolnjen, imena pa nato glasoslovno-pravopisno poknjižena. Do konca leta 2020 je bilo tako zbranih in objavljenih že čez 12.100 hišnih imen v 380 naseljih 22 občin, s tablicami s hišnimi imeni je bilo označenih okrog 7000 domačij. Doslej je bilo izdanih 46 publikacij s hišnimi imeni. Septembra 2020 je bila enota Raba hišnih imen vpisana v nacionalni Register nesnovne kulturne dediščine (http://www. nesnovnadediscina.si/sl/register/raba-hisnih-imen).

${ }^{4}$ FLU-LED je bil mednarodni projekt Slovenske prosvetne zveze in Krščanske kulturne zveze iz Avstrije ter Razvojne agencije Zgornje Gorenjske in Gornjesavskega muzeja Jesenice iz Slovenije ter strokovnih partnerjev Slovenskega narodopisnega inštituta Urban Jarnik iz Celovca in Inštituta za slovenski jezik Frana Ramovša ZRC SAZU iz Ljubljane. Projekt, ki je potekal v letih 2011-2014 na območju Južne Koroške (Avstrija) in Zgornje Gorenjske (Slovenija), je bil financiran v okviru evropskega Programa čezmejnega sodelovanja INTERREG IV SI-AT 2007-2013. Čezmejni projekt s svojim nadaljevanjem je bil leta 2020 izbran v nabor dobrih praks Evropske unije (http://www.culturalheritageinaction.eu/culture/resources/GORENJSKA-REGION-Name-it-in-Slovenian-Cross-border-collaboration-and-citizens-engagement-to-preserve -traditional-house-and-field-names-WEBP-BWXLJR). 


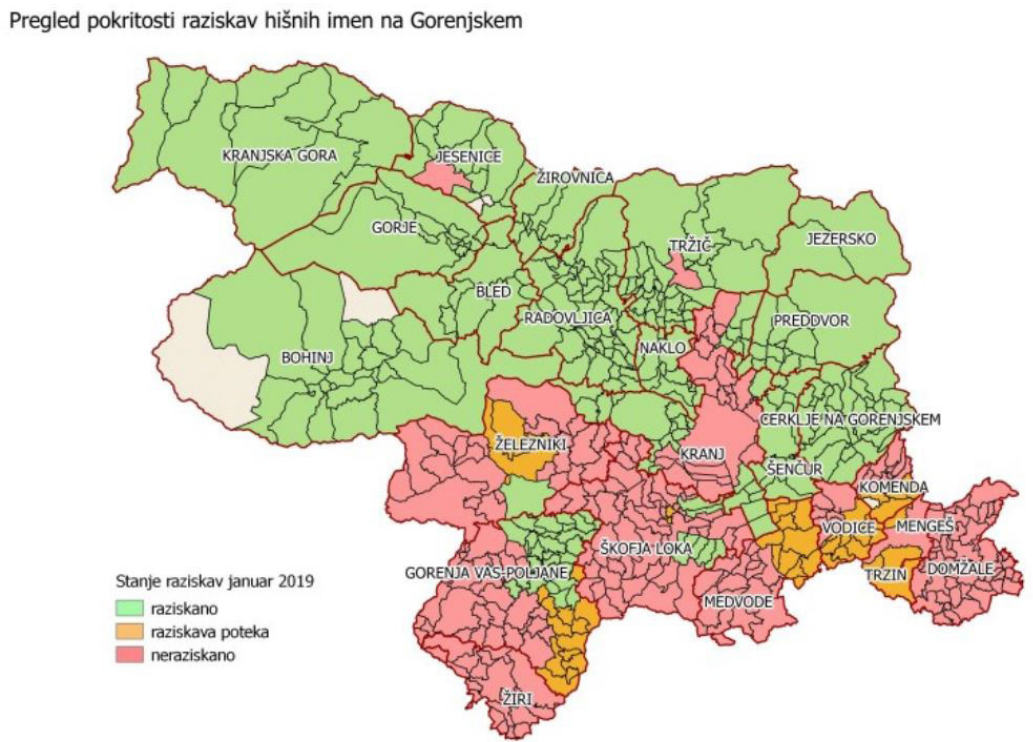

Il. 1. V projektu Kako se pri vas reče? obravnavano območje (https://www.hisnaimena.si/o_projektu/)

imena imajo pri identifikaciji domačinov pogosto celo pomembnejšo vlogo kot njihov priimek in posameznike običajno spremljajo vse življenje - pogosto so ob imenu in priimku zapisana tudi na nagrobnikih. Tvorjena so lahko iz osebnih lastnih imen (rojstnih imen, priimkov, vzdevkov) gospodarjev in (redko) gospodaric, iz njihovega geografskega porekla, poimenovanj za poklic ali družbeni status lastnika, poimenovanj za vrste stavb (glede na njihov videz ali funkcijo), iz poimenovanj značilnih rastlin in živali, lokacije domačije ipd.

\section{Narečni leksemi s pomenom 'kmet', 'gruntar' in 'bajtar' v Slovenskem lingvističnem atlasu (SLA)}

$\mathrm{V}$ članku $\mathrm{k}^{5}$ so izbrana hišna imena primerjana $\mathrm{z}$ apelativi, zbranimi $\mathrm{v}$ okviru dolgoročnega projekta Slovenski lingvistični atlas (SLA), kamor je bilo v letih 1947-2020 na Gorenjskem z enotno anketno metodo zajetih 52 krajevnih govorov. Ti krajevni govori spadajo tako v narečja gorenjske narečne skupine (gorenjsko narečje v T195T218, vzhodnogorenjsko podnarečje v T219-T227 in selško narečje v T188-T194) kot tudi rovtarske narečne skupine (škofjeloško v T185-T187 in poljansko narečje v T178T184) ter koroške narečne skupine (ziljsko narečje v T008 in kranjskogorsko podnarečje v T009).

\footnotetext{
${ }_{5}^{5}$ Besedilo je bilo pripravljeno z vnašalnim sistemom ZRCola (http://zrcola.zrc-sazu.si), ki ga je na Znanstvenoraziskovalnem centru SAZU v Ljubljani (http://www.zrc-sazu.si) razvil Peter Weiss.
} 


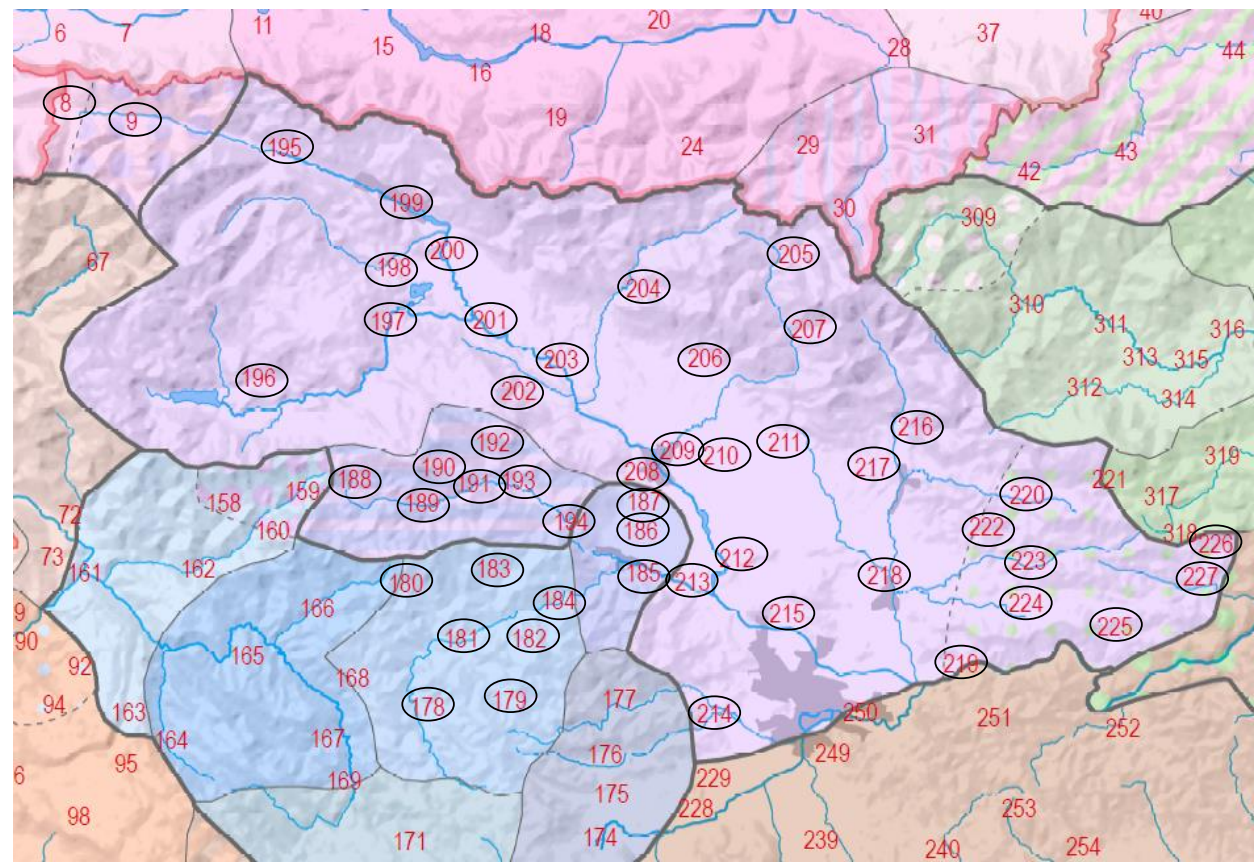

Il. 2. V raziskavo zajete točke Slovenskega lingvističnega atlasa na Gorenjskem (podlaga: Karta slovenskih narečij, Slovenski lingvistični atlas 2.1, www.fran.si, 26. 2. 2021)

Vsi informanti ${ }^{6}$ so odgovarjali na vprašanja iz vprašalnice za Slovenski lingvistični atlas (prim. Benedik 1999, 15-17). Tu obravnavana vprašanja V181 kmet, V185 gruntar in V186 bajtar so uvrščena v poglavje $\mathrm{Vas}^{7}$, zapisano gradivo pa je del indeksov za omenjena vprašanja, obravnavana v SLA 3 (v nastajanju).

Za razumevanje zgodovinskega in sodobnega položaja kmečkega posestnika v slovenski družbi in njegove vloge $\mathrm{v}$ javnem življenju je pomembna označitev kmečkega prebivalstva po njegovem premoženjskem stanju in s tem povezanem družbenem položaju. Na Slovenskem se je na podlagi presoje obsega lastništva zemlje in grajenih stavb, nepremičnih in premičnih naprav, orodij, prevoznih sredstev, strojev idr. izoblikovala razdelitev kmetov po njihovem gmotnem položaju. Zato je tudi popis in ovrednotenje zemljišč, npr. v franciscejskem katastru (FK) iz srede prve polovice 19. stoletja, temeljil na označevanju kmetov po njihovem gmotnem položaju. Najbolj značilna in splošno razumljiva družbena delitev kmetov tako v njihovem okolju kot v državnopravnih ustanovah in zakonodaji je (bila) delitev na velike, srednje in male kmete ter lastnike

\footnotetext{
${ }^{6}$ Informanti so bili domačini, rojeni večinoma v 1. polovici 20. stoletja, ki so večji del svojega življenja preživeli v domačem kraju in so bili tako kompetentni govorci krajevnega govora in dobri poznavalci domačega okolja.

${ }^{7}$ Gradivo je v skladu z dogovorom pri projektu SLA navedeno tako, kot je zapisano v arhivu Dialektološke sekcije Inštituta za slovenski jezik Frana Ramovša ZRC SAZU v Ljubljani, čeprav se je način fonetične transkripcije v času zbiranja gradiva nekoliko spreminjal (prim. Benedik 1999, 20-22).
} 
Preglednica 1. Narečni apelativi s pomenom 'kmet', 'gruntar' in 'bajtar' v Slovenskem lingvističnem atlasu

\begin{tabular}{|c|c|c|c|c|}
\hline Točka & Kraj in leto zapisa & V181.01 kmet & V185.01 gruntar & V186.01 bajtar \\
\hline \multicolumn{5}{|c|}{ ziljsko narečje } \\
\hline T008 & Rateče (1952) & kmẹ̈t, pávər; k'met & bẹ́läk kmẹ̈t; grù:ntar & $\begin{array}{l}\text { bâitar, kâižar, mîxñ } \\
\text { kmẹtt; kà:inžar }\end{array}$ \\
\hline \multicolumn{5}{|c|}{ kranjskogorsko podnarečje } \\
\hline T009 & Kranjska Gora $(1959,1969)$ & kmə̈t, pâuِər; kmə̀t & grûntar; grúntar & kâižar; bâitar \\
\hline \multicolumn{5}{|c|}{ poljansko narečje } \\
\hline $\mathrm{T} 178$ & Dobračeva (1972) & kmòt & rrûntar & báitar \\
\hline $\mathrm{T} 179$ & Lučine (1982) & x'met, k'met & $\gamma^{\prime}$ runtar & bá:jtar \\
\hline $\mathrm{T} 180$ & Leskovica (1966) & xmệt & xmệt & bâitar \\
\hline T181 & $\begin{array}{l}\text { Gorenja vas - Poljane } \\
(1946-1952)\end{array}$ & xmẹ̄t; k'met & rrûntar; $\gamma^{\prime}$ runtar & bâitar; bá:intar \\
\hline $\mathrm{T} 182$ & Bukov Vrh (1983) & x'met & $\gamma^{\prime}$ runtar & bá:jtar \\
\hline T183 & Javorje (1948) & xmẹ̄t & rrûntar & bâitar \\
\hline T184 & Gabrk (1964) & kmệt & rrûntar & bâitar \\
\hline \multicolumn{5}{|c|}{ škofjeloško narečje } \\
\hline $\mathrm{T} 185$ & Pungart (1971) & kmët & rrüntar & bâitar \\
\hline T186 & Žabnica (1960) & kmẹ̈t & rrüntar & bâitar \\
\hline $\mathrm{T} 187$ & $\begin{array}{l}\text { Zgornje Bitnje }(1948,1963, \\
1971,1972)\end{array}$ & $\begin{array}{l}\text { kmẹt; kmệt; kmẹit, } \\
\text { pâvər; pávər, kmẹ̈t }\end{array}$ & 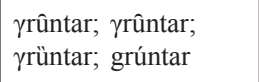 & $\begin{array}{l}\text { bâitar, yostäč; } \\
\text { bâitar; bâitar; bájtar }\end{array}$ \\
\hline \multicolumn{5}{|c|}{ selško narečje } \\
\hline T188 & Zgornja Sorica (1947) & kmệt & rrûntar & kâižar \\
\hline T189 & Zali Log (1947) & kmẹ̈t & rrûntar & bâiitar, kâižar \\
\hline $\mathrm{T} 190$ & Podlonk (1947) & kmẹtt & rrûntar & bâitar \\
\hline $\mathrm{T} 191$ & Železniki (1947, 1979) & kmẹit; kmët & 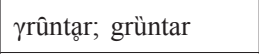 & bâitạ,, xlệvər; bâitar \\
\hline T192 & Dražgoše (1947) & /; k'mət & 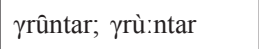 & /; kà:jžar, bà:jtar \\
\hline T193 & Selca $(1947,1968-1969)$ & kmẹ̀t; kmët & rrûntar; grûntar & bâitar; bâitar, kâižar \\
\hline T194 & Praprotno (1947) & l & rrûntar & bâitar \\
\hline \multicolumn{5}{|c|}{ gorenjsko narečje } \\
\hline T195 & Dovje (1947) & kmệt, pâuِrr & grûntar & bâjtar \\
\hline T196 & $\begin{array}{l}\text { Srednja vas v Bohinju } \\
(1954)\end{array}$ & pâuِər & l & bâitar \\
\hline T197 & Bohinjska Bela (1959-1960) & kmët & grûntar, kâižarar & bâitar \\
\hline T198 & Zgornje Gorje (1976) & kmèt, pávər & grûntar, kmèt & bâitar, kâižar \\
\hline
\end{tabular}




\begin{tabular}{|c|c|c|c|c|}
\hline T199 & Slovenski Javornik (1959) & kmę̂t & grúntar & bâitar \\
\hline $\mathrm{T} 200$ & Breg (1962) & kmę̂t & grûntar, kmetâuzar & bâintar, kâižar \\
\hline $\mathrm{T} 201$ & Radovljica $(1959,2009)$ & $\begin{array}{l}\text { kmęt; grù:ntar, } \\
\text { k' met }\end{array}$ & grûntar; grù:ntar & bâitar; bà:intar \\
\hline T202 & Kropa $(1952,1975,1993)$ & kmệt; kmệt; k'met & $\begin{array}{l}\text { /; kmẹtt, grúntar; } \\
\text { gRùntar, vé:lək } \\
\text { k'met }\end{array}$ & $\begin{array}{l}\text { /; bâitaŕ, kâizar̉ [!]; } \\
\text { kà:ižar }\end{array}$ \\
\hline $\mathrm{T} 203$ & Ljubno (1959) & kmệt & grûntar & bâitar \\
\hline $\mathrm{T} 204$ & Lom pod Storžičem (1967) & kmệt & grûntar & bâitar \\
\hline $\mathrm{T} 205$ & Zgornje Jezersko (1953) & kmệt & l & kâižlar \\
\hline T206 & Bašelj $(1947,1971)$ & kmệt; kmêt & grûntar; $\gamma$ rûntar & bâitar; bâitar \\
\hline $\mathrm{T} 207$ & Kokra (1959) & kmẹtt, pâuər & rrûntar & bâitar \\
\hline T208 & $\begin{array}{l}\text { Stražišče (Kranj) (1947, } \\
\text { 1959, 1967) }\end{array}$ & kmẹt; kmệt; kmę̆t & 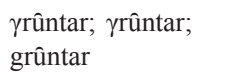 & bâitar; bâitar; bâitar \\
\hline T209 & $\begin{array}{l}\text { Primskovo (Kranj) } \\
(1959-1960)\end{array}$ & kmệt & rrûntar & bâitar \\
\hline $\mathrm{T} 210$ & Šenčur (1961) & kmệt & rrûntår & bâitąr \\
\hline $\mathrm{T} 211$ & $\begin{array}{l}\text { Cerklje na Gorenjskem } \\
(1947, ?)\end{array}$ & $\begin{array}{l}\text { kmệt, pảvər; kmệt, } \\
\text { páwər }\end{array}$ & rrûntar; $\gamma$ rûntar & bâîtar; bâitar \\
\hline $\mathrm{T} 212$ & Valburga (1959-1960) & kmệt & rrûntar & bâitar \\
\hline $\mathrm{T} 213$ & Spodnja Senica (1998) & k'met, k'me:t & rrûntər & bâitər, kà:ižər \\
\hline $\mathrm{T} 214$ & Dobrova (?) & kmệt & rrûntar & bâitar \\
\hline $\mathrm{T} 215$ & Zgornje Gameljne (1959) & kmệt & rrûntar & bâitar \\
\hline $\mathrm{T} 216$ & Črna pri Kamniku (1960) & páűər, kmệt & rrûntar & kâižar \\
\hline $\mathrm{T} 217$ & Tunjice (1974) & kmę̀t & rrûntar & bâitar \\
\hline $\mathrm{T} 218$ & Srednje Jarše (1983) & kmè:t & $\gamma$ rù:ntar & bà:jtar \\
\hline \multicolumn{5}{|c|}{ vzhodnogorenjsko podnarečje } \\
\hline T219 & Dolsko (1960) & kmệt & rrûntar & bâitar \\
\hline $\mathrm{T} 220$ & Stebljevek (1951) & kmệt & việlk $\gamma$ rûntar & bâitar \\
\hline $\mathrm{T} 221$ & $\begin{array}{l}\text { Okrog pri Motniku } \\
(1960-1961)\end{array}$ & kmę̈t & rrûntar & bâitar \\
\hline $\mathrm{T} 222$ & Obrše (1951) & kmệt & $\gamma$ rûntar & bâitar \\
\hline $\mathrm{T} 223$ & Krašnja (1951) & kmệt, pâvər; k'met & 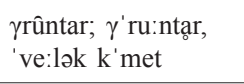 & bâitar; 'ba:itar \\
\hline $\mathrm{T} 224$ & Moravče (1951) & kmę̂t & rrûntar & bâitar \\
\hline $\mathrm{T} 225$ & Vače (1952) & kmệt, kmầt, pâvər & l & l \\
\hline $\mathrm{T} 226$ & Čemšenik (1952) & kmệt, pâvar & vệlk pâvar & kûočar \\
\hline $\mathrm{T} 227$ & Izlake (1952) & pâvər & grûntar, việlk pâvər & bâitar, kộčar \\
\hline
\end{tabular}


nadpovprečno obsežnih zemljišč - veleposestnike, ponekod tudi gruntarje, in lastnike zelo majhnih zemljiških posesti z le eno ali dvema stavbama - bajtarje. Vrednost kmečkih posesti so ocenjevalci in odmerjevalci davkov praviloma določali ne le glede na površinski obseg kmetiji pripadajočih zemljišč, ampak tudi glede na njihovo donosnost $-\mathrm{z}$ donosnostjo zemljišč so se izoblikovale tudi različne predstave o dohodkovnem in s tem premoženjskem stanju kmetov. Pojmovanje razlik v velikosti kmečke posesti in družbenem položaju kmetov je bilo zato v različnih (naravnih) okoljih zelo različno ${ }^{8}$.

\section{Kmet}

Kmet je oseba, ki je lastnik zemlje, ki jo obdeluje in se s tem povsem ali deloma preživlja. Najpogosteje je kmet posestnik njiv, travnikov in gozdov ter ponekod tudi senožeti in gorskih pašnikov, pa tudi manj rodnih ali povsem kamnitih gorskih površin. Gospodarske in politične spremembe po 2. svetovni vojni so v Sloveniji zmanjšale število kmetov - po uveljavitvi zemljiškega maksimuma in omejevanju nekaterih pravic do uporabe vodnih virov so se namreč občutno krčile možnosti samozadostnega kmečkega gospodarjenja, zato so se številni kmetje zaposlovali v industriji, postali so t. i. polkmetje, nekateri so celo opustili kmetovanje?

\section{Morfološka analiza narečnih leksemov:}

kmet $<*(k b m e t)-b \leftarrow$ rom. ${ }^{*}$ comete $<$ lat. comes, rod. comitis 'spremljevalec, družabnik' (z narečno asimilacijo $k m \geq x m$ v T179, T181-T183 [Ramovš 1924, 230]); paver $<*$ (pavr) $-\mathrm{b} \leftarrow$ nem. Bauer 'kmet' v bav. nem. izgovoru ( $b->p$-); gruntar $<*$ (grunt) $-a \dot{r}-b \leftarrow$ srvnem. grunt 'tla, zemlja, posestvo', nem. Grunt 'tla, zemlja, temelj, osnova'.

\section{Gruntar}

Gruntar je oseba, ki ima v lasti večje površine obdelovalne zemlje in gozda - gruntarska kmetija, $\mathrm{v}$ fevdalizmu tudi huba, je v našem prostoru običajno zavzemala okrog 12 hektarjev obdelovalne zemlje, tj. toliko, da je na njej lahko preživela ena družina. V nekaterih vzhodnih delih osrednje Slovenije se je beseda gruntar obdržala predvsem kot oznaka za nadpovprečno premožnega kmeta, mlinarja, žagarja in trgovca z lesom, ki je bil lastnik ne le obsežnih gozdov in obdelovalne zemlje, ampak lahko tudi več arhitekturno prestižnejših stanovanjskih stavb in različnih gospodarskih poslopij. Vidne in $\mathrm{v}$ prvotni podobi zadovoljivo ohranjene gruntarske posesti in predvsem njihove

${ }^{8}$ Družbenozgodovinska in etnološka predstavitev kmečkih posestnikov je $\mathrm{v}$ tem članku povzeta po Etnoloških pojasnilih, ki jih je za vprašanja V181 kmet, V185 gruntar in V186 bajtar za Slovenski lingvistični atlas 3 pripravil prof. dr. Vito Hazler s Filozofske fakultete Univerze v Ljubljani.

${ }^{9}$ Po podatkih Statističnega urada Republike Slovenije je v Sloveniji okrog 70.000 kmetijskih gospodarstev - vsako „obdeluje povprečno 6,8 hektarja kmetijskih zemljišč v uporabi, gospodari s povprečno 5,6 hektarja gozda in redi povprečno 6,0 glave velike živine" (vir: https://www.stat.si/StatWeb/News/Index/6208, dostop 1. 3. 2021.) Približno $80 \%$ kmetij se ukvarja z živinorejo. 


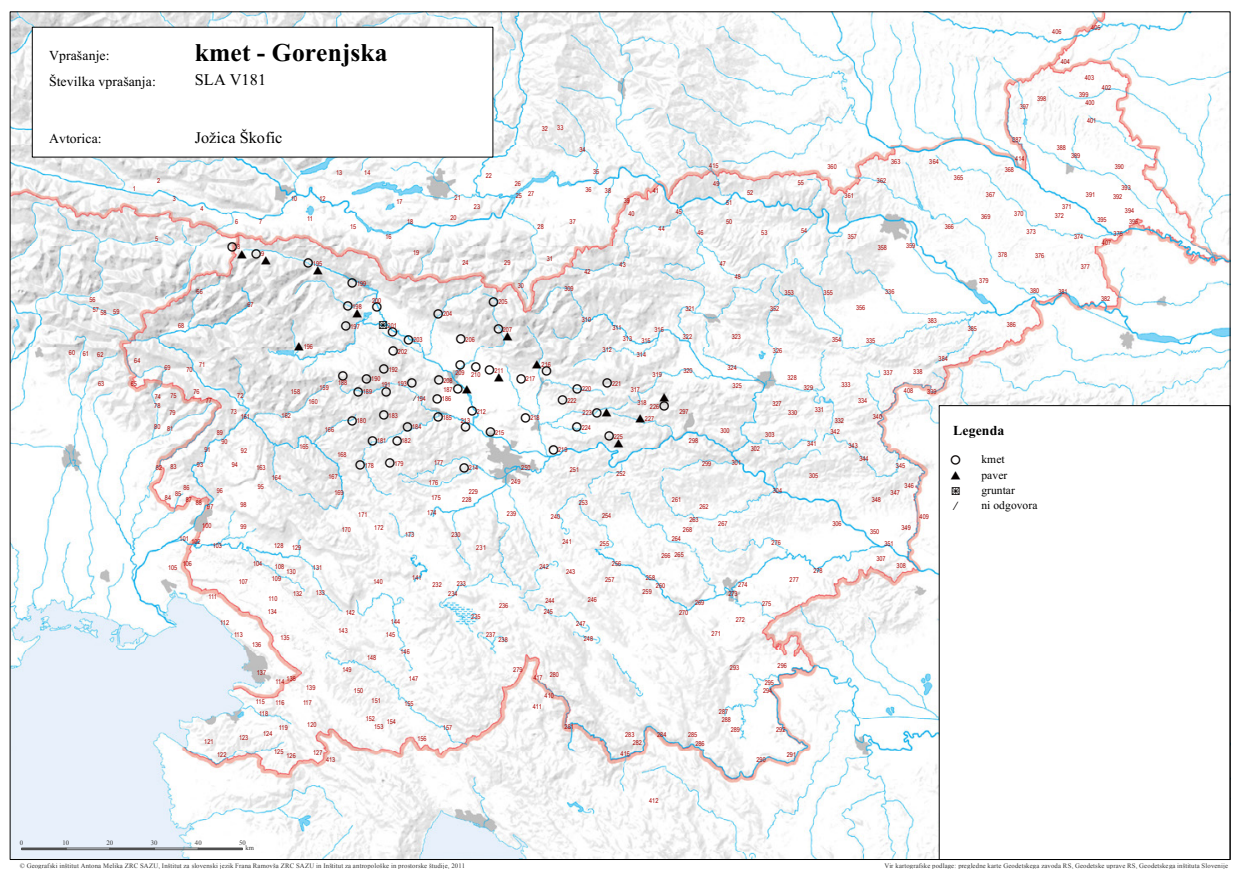

Il. 3. Leksemi s pomenom 'kmet' v krajevnih govorih Slovenskega lingvističnega atlasa na Gorenjskem

stanovanjske in gospodarske stavbe so od 80 . let 20. stoletja tudi predmet spomeniškovarstvenih obravnav.

\section{Morfološka analiza narečnih leksemov:}

kmet $<*(k b m e t)-b \leftarrow$ rom. ${ }^{*}$ comete $<$ lat. comes, rod. comitis 'spremljevalec, družabnik' (z narečno asimilacijo $k m \geq x m$ v T180 [Ramovš 1924, 230]);

velik kmet $<*^{*}$ vel-ik-b(-j-b) (kbmet)-b $\leftarrow *^{*}$ vel-ik-b 'velik' ( $\leftarrow *$ vel-b 'velik') + rom. * comete;

$\operatorname{kmetavzar}^{10}<*(k ъ m e t)-a v-b z-a \dot{r}-b$

gruntar $<*$ (grunt)-aŕ-b $\leftarrow$ srvnem. grunt 'tla, zemlja, posestvo', nem. Grunt 'tla, zemlja, temelj, osnova';

velik gruntar $<* v e l-i k-b(-j-b)$ (grunt)-aŕ-b $\leftarrow *^{*} v e l-i k-b$ 'velik' ( $\leftarrow * v e l-b$ 'velik') + srvnem. grunt;

velik paver $<*$ vel-ik-b(-j-b) (pavr)-b $\leftarrow * v e l-i k-b$ 'velik' $(\leftarrow * v e l-b$ 'velik') + nem. Bauer 'kmet';

kajžar $<*(k a j z ̌)-a \dot{r}-b \leftarrow *(k a j z ̌)-a \leftarrow$ bav. nem. Kaise, Kaische, Keische 'kajža, koča' (pred prehodom $* \dot{\mathrm{Z}}>\grave{s}$ ).

${ }^{10}$ Beseda ima v slovenskem knjižnem jeziku slabšalno konotacijo. 


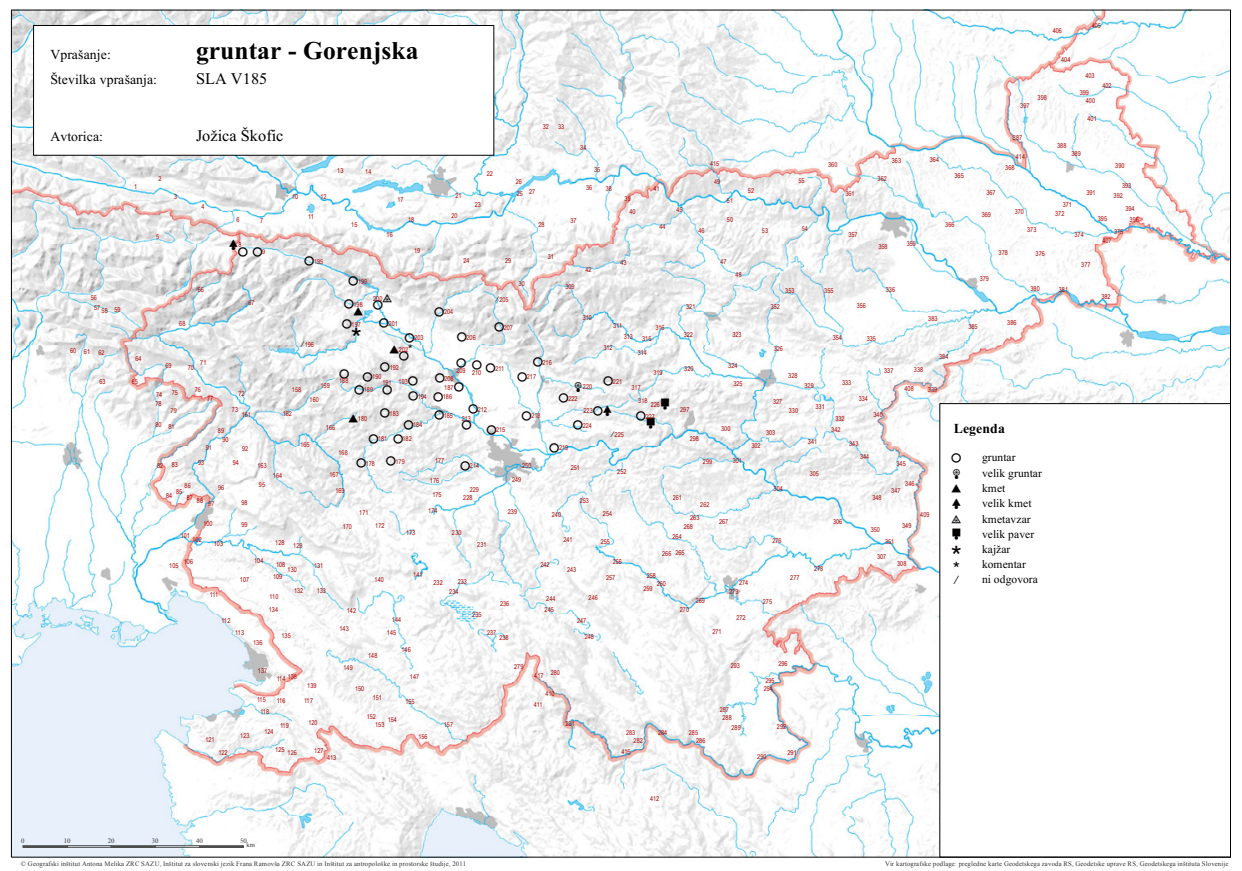

I1. 4. Leksemi s pomenom 'gruntar' v krajevnih govorih Slovenskega lingvističnega atlasa na Gorenjskem

\section{Bajtar}

Bajtar je bil manjši posestnik, ki je z družino ali tudi sam stanoval v manjši, delno leseni stanovanjski hiši, ki se je ponekod podaljševala v manjši, največkrat le enoprostorni gospodarski prostor. Bajtar je imel v lasti zelo malo zemlje, ponekod dovolj le za rejo nekaj perutnine ali tudi eno ali dve kozi ali ovci. Po gmotnem položaju je bil večinoma $\mathrm{v}$ ugodnejšem položaju od najemniških kočarjev, ki so prebivali v lesenih ali delno lesenih najetih kočah kmečkih gospodarjev. V stavbnem in družbenem okolju bajtarjev so se še v 1. polovici 20. stoletja dlje kot pri drugih družbenih skupinah ohranile prvobitne enoprostorne hiše ognjiščnega in kasnejšega dimničnega tipa ter preproste hiše s samo dvema prostoroma, odprto vhodno vežo z odprtim kuriščem za peč v sosednji bivalni hiši, kakor so v večini slovenskega ozemlja imenovali osrednji bivalni prostor, kjer so stanovalci bivali, se prehranjevali, prenočevali, opravljali različna hišna in rokodelska dela. Kljub skromni bivalni rávni bajtarjev zlasti s primerljivim večinskim kmečkim prebivalstvom ter obrtniškim in delavskim prebivalstvom v vaseh, trgih in mestih pa urejenost in čistoča bajtarskih domov ni bila vedno nizka, pogosto je celo bistveno presegala raven nekaterih gmotno močnejših kmetov in tudi delavstva. Hiše bajtarjev pa so bile zaradi njihovih gmotnih razmer pogosto slabše gradbene kakovosti, zato so te stavbe dajale videz dotrajanih, pogosto tudi slabo vzdrževanih stavb. 


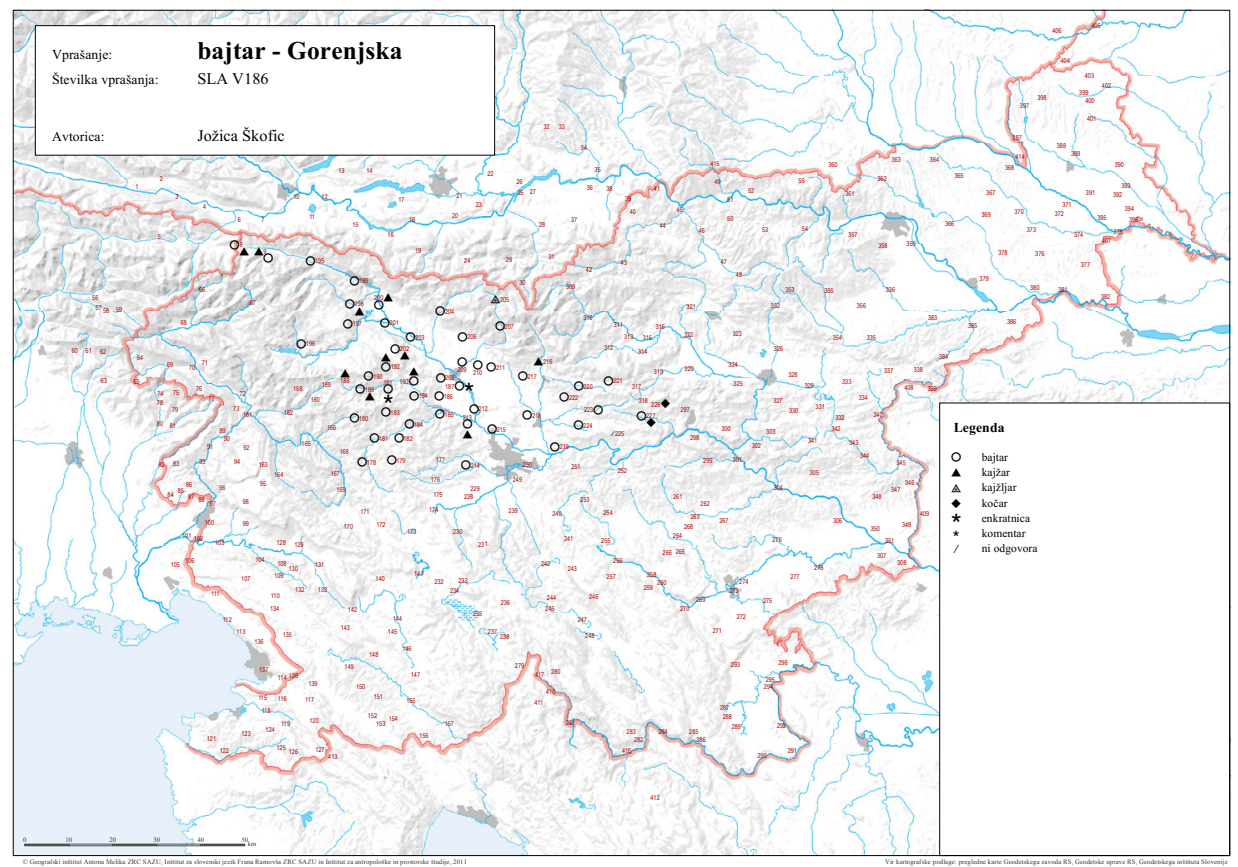

Il. 5. Leksemi s pomenom 'bajtar' v krajevnih govorih Slovenskega lingvističnega atlasa na Gorenjskem

\section{Morfološka analiza narečnih leksemov:}

bajtar $<*$ (bajt)-aŕ-b $\leftarrow *$ (bajt)- $a \leftarrow$ ben. it. baita, furl. baite 'koča, bajta';

kajžar $<*(k a j z ̌)-a \dot{r}-b \leftarrow$ bav. nem. Kaische, Keische 'kajža, koča' (pred prehodom $* \dot{\mathrm{Z}}>\check{s})$

kajžljar $<*(k a j z ̌ l a r ́)-b$, avstr. nem. Keuschler v nar. nem. izgovoru (eu $>a i$, pred prehodom $\dot{\mathrm{Z}}>\check{s}$ );

majhen kmet $<*$ mal-ix-bn-b (kbmet)- $b \leftarrow *^{*}$ mal-b 'majhen' $+*(k b m e t)-b \leftarrow$ rom. *comete < lat. comes, rod. comitis 'spremljevalec, družabnik';

gostač $<*$ gost-ač-b $\leftarrow$ *gost-b 'gost';

hlevar $<* x l e \check{v}-a \dot{r}-b \leftarrow * x l e ̌ v-b$ 'hlev, staja'.

\section{Hišna imena, nastala iz poimenovanj za kmečke posestnike}

Hišna imena na Gorenjskem so praviloma sestavljena iz predloga pri (<* pri 'pri') in samostalnika - lastnega ali občnega imena, ki je motiviralo nastanek hišnega imena, v mestniku ednine (s končnico $-u$ za samostalnike moškega spola, ki pa je v narečjih lahko oslabela v polglasnik ali onemela). Na Gorenjskem so hišna imena, nastala iz poimenovanj za večje kmečke posestnike, kmete in gruntarje, zelo redka, pogostejša pa 
so hišna imena, nastala iz občnih poimenovanj manjših posestnikov, bajtarjev in kajžarjev ${ }^{11}$. Lastna imena, nastala iz apelativa gruntar, na Gorenjskem doslej sploh še niso bila zabeležena.

V nadaljevanju je predstavljeno zbrano imensko gradivo, ki je tudi morfološko analizirano.

\section{Hišna imena, tvorjena iz apelativa $\boldsymbol{k m e t}^{12}$}

\begin{tabular}{|l|l|l|l|}
\hline \multicolumn{1}{|c|}{ Pri Kmetu } & \multicolumn{1}{|c|}{ Gospodar } & \multicolumn{1}{c|}{ Kraj } & \multicolumn{1}{c|}{ Zgodovinski zapis } \\
\hline Pər Kmét & Kmèt & $\begin{array}{l}\text { Bohinjska } \\
\text { Bistrica }\end{array}$ & FK $^{13}$ 1827: Kmet \\
\hline Par Kmét & Kmèt & Mavčiče & SA 1823-1829: Kmet \\
\hline Par Kmét & Kmèt & Nemilje & RK 1869: Kmet, SA 1812-1906: Kmet \\
\hline Par Kmêt & Kmèt & Javornik & SA 1803-1910: Kmet \\
\hline
\end{tabular}

pri kmetu $<*$ pri 'pri' $+(k ъ m e t)-ъ(\leftarrow$ rom. *comete $<$ lat. comes, rod. comitis 'spremljevalec, družabnik');

\begin{tabular}{|l|l|l|l|}
\hline Pri Kmetiču & \multicolumn{1}{|c|}{ Gospodar } & \multicolumn{1}{c|}{ Kraj } & \multicolumn{1}{c|}{ Zgodovinski zapis } \\
\hline Par Kméč & Kméč & $\begin{array}{l}\text { Bukovica pri } \\
\text { Vodicah }\end{array}$ & FK 1827: Kmetizh, SA 1751-1863: Kmetizh \\
\hline
\end{tabular}

pri kmetiču $<*$ pri 'pri' $+(k ъ m e t)-i t$ '- $(\leftarrow(k ъ m e t)-b)$.

Narečna oblika kméč je nastala po onemitvi ponaglasnega $-i-\mathrm{v}$ priponi $-i c ̌$ in nato asimilaciji soglasnikov na korenskem šivu $-t \check{c}-\mathrm{v}-\check{c}-$.

\section{Hišna imena, tvorjena iz apelativa paver}

\begin{tabular}{|l|l|l|l|}
\hline \multicolumn{1}{|c|}{ Pri Pavru } & \multicolumn{1}{|c|}{ Gospodar } & \multicolumn{1}{|c|}{ Kraj } & \multicolumn{1}{c|}{ Zgodovinski zapis } \\
\hline Par Pávrə & Pávar & Ovsiše & $\begin{array}{l}\text { FK 1827: Paver, SA 1774-1855: Pauer, SA } \\
\text { 1814-1894: Paver }\end{array}$ \\
\hline Par Pávrə & Pávar & Žiganja vas & $/$ \\
\hline Par Pávra & Pávar & Mlaka & SA 1902: Pauer \\
\hline
\end{tabular}

pri pavru < *pri 'pri' +*(pavr)-ъ $(\leftarrow$ nem. Bauer 'kmet' v bav. nem. izgovoru $[b->$ $p$-]).

11 Velike kmetije imajo pogosto svoja imena motivirana z rojstnimi imeni, priimki, vzdevki prvotnih gospodarjev, pogosto tudi z geografsko lego domačije.

12 Slovarske razlage so iz Slovarja slovenskega knjižnega jezika, dostopnega na www.fran.si: $k$ met 'kmet ima zemljo in jo obdeluje ter se s tem preživlja'.

${ }^{13}$ FK - Franciscejski kataster 1827, RK - Reambulančni kataster 1867-1869, SA - Status animarum (̌̌upnijski popis duš). 


\section{Hišna imena, tvorjena iz apelativa bajta $^{14}$}

$\mathrm{Na}$ Gorenjskem je bilo zabeleženih več hišnih imen, nastalih iz apelativa bajta. Večinoma so to besedne zveze iz levega pridevniškega prilastka, ki označuje (nekdanjega) lastnika, in apelativa bajta v jedru samostalniške besedne zveze. Pridevniški prilastek je navadno tvorjen s svojilno pripono -ov-a $\left(<*_{-o v-a}\right)$ oz. -ev-a $\left(<*_{-} \text {ev-a }\right)^{15}$, tj. Ahčova bajta, Anžkova bajta, Arnešova bajta, Boštjanova bajta, Frjanova bajta, Govčeva bajta, Habjanova bajta, Hočevarjeva bajta, Jelerjeva bajta, Jerajova bajta, Jožkova bajta, Jurčeva bajta, Koblančeva bajta, Končeva bajta, Koroščeva bajta, Kosova bajta, Kovkarjeva bajta, Lenartova bajta, Makekova bajta, Maželjnova bajta, Mihovčeva bajta, Mikvavova bajta, Murenčeva bajta, Petrovčova bajta, Rakova bajta, Rebovova bajta, Repnekova bajta, Roblekova bajta, Robovčova bajta, Rojčova bajta, Rotarjova bajta, Skubrova bajta, Šepcova bajta, Španova bajta, Vorvova bajta, Žerovčeva bajta, Žmitkova bajta. Redkejše so pripone -ja $\left(<*_{-}\right.$-j-a), tj. Bužeča bajta, Bvagneča bajta, Smoleča bajta, Žimanča bajta, pripona -na (*ьn-a oz. *-bn-b-j-a), tj. Cestna bajta, in pripona

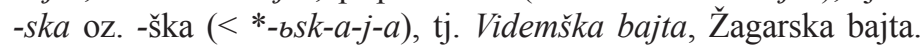

Take samostalniške zveze se kot hišno ime pojavljajo tako $\mathrm{v}$ imenovalniku ednine kot v obliki mestnika ednine skupaj s predlogoma pri ali $v(<* v b(n)$ 'v'): Pri Gvahkovi bajti, Pri Nančni bajti ter $V$ Benetkovi bajti, V Janezovi bajti, V Jernejcovi bajti, $V$ Jesenkovi bajti, V Kožuhovi bajti, V Lazarjevi bajti, V Mežnarjevi bajti, V Mrakovi bajti, V Muhovi bajti, V Oblakovi bajti, V Opočenovi bajti, V Pečelarjevi bajti, V Prodovski bajti, $V$ Španovi bajti, $V$ Žagarjevi bajti.

Apelativ bajta se kot hišno ime v mestniku ednine s predlogom pri ali $v$ uporablja tudi brez pridevniškega prilastka: Pri Bajti, V Bajti.

Hišno ime, nastalo iz apelativa bajtar, je na Gorenjskem redko:

\begin{tabular}{|l|l|l|l|}
\hline \multicolumn{1}{|c|}{ Pri Bajtarju } & \multicolumn{1}{|c|}{ Gospodar } & \multicolumn{1}{c|}{ Kraj } & \multicolumn{1}{c|}{ Zgodovinski zapis } \\
\hline Par Bájtari & Bájtar & Četena Ravan & SA 1820-1900: Bajtar \\
\hline Par Bájtarja & Bájtar & Železniki & SA 1850-1970: Bajtar \\
\hline
\end{tabular}

Narečna končnica $-i$ je nastala po podaljšavi osnove na $-r$ z $-j$ - in oslabitvi izglasnega $-u \mathrm{v}$ polglasnik ter nato asimilaciji $-j-\partial>-i$.

Druge izpeljanke, ki označujejo lastnika ali stanovalca bajte, so tvorjene s priponami -en $\left(<*_{-b n-b}\right.$ oz. *-bn-bj-b) kot posamostaljeni svojilni pridevnik v ednini ali mno-

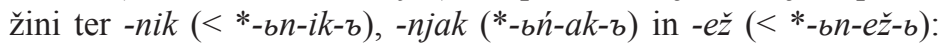

\begin{tabular}{|c|l|l|l|}
\hline Pri Bajtini & \multicolumn{1}{|c|}{ Gospodar } & \multicolumn{1}{|c|}{ Kraj } & \multicolumn{1}{c|}{ Zgodovinski zapis } \\
\hline Par ta Bájtnə & $/$ & Žeje & SA 1814-1906: Rantčeva bajta \\
\hline
\end{tabular}

\footnotetext{
14 SSKJ (Slovar slovenskega knjižnega jezika): bajta 'majhna, preprosta hiša' in 'zelo majhno posestvo'.

15 Preglas -o- > -e-za palatali je v narečjih redek.
} 
pri bajtini (sg.) <*pri 'pri' + *(bajt)-bn-aj-a (Lsg. *-ij-i) $(\leftarrow *$ (bajt)-a $\leftarrow$ ben. it. baita, furl. baite 'koča, bajta');

\begin{tabular}{|l|l|l|l|}
\hline Pri Bajtinih & \multicolumn{1}{|c|}{ Gospodar } & \multicolumn{1}{|c|}{ Kraj } & \multicolumn{1}{c|}{ Zgodovinski zapis } \\
\hline Par Bájtnəh & Bájtən & $\begin{array}{l}\text { Ambrož pod } \\
\text { Krvavcem }\end{array}$ & $/$ \\
\hline Par Bájtnəh & Ta Bájtən & Breg ob Savi & SA 1900-1950: Polenčeva kajža \\
\hline Par Bájtnəh & Bájtən ... & $\begin{array}{l}\text { Cerklje na } \\
\text { Gorenjskem }\end{array}$ & $/$ \\
\hline Par Bájtnəh & Bájtən ... & Moste & SA 1902: V Bajti \\
\hline
\end{tabular}

pri bajtinih (pl.) <*pri 'pri' $+*$ (bajt)-bn-bj-b (Lpl. -ij-ixb) $(\leftarrow *($ bajt $)-a \leftarrow$ ben. it. baita, furl. baite 'koča, bajta');

\begin{tabular}{|l|l|l|l|}
\hline Pri Bajtniku & \multicolumn{1}{|c|}{ Gospodar } & \multicolumn{1}{|c|}{ Kraj } & \multicolumn{1}{c|}{ Zgodovinski zapis } \\
\hline Par Bájtnk & Bájtnk & Pevno & SA 1830-1950: Kajža \\
\hline Par Bájtnek & Bájtən ... & Smlednik & $/$ \\
\hline Par Bájtnek & Bájtən ... & Vodice & $/$ \\
\hline
\end{tabular}

pri bajtniku < *pri 'pri' + *(bajt)bnik-ъ ( $\leftarrow$ ben. it. baita, furl. baite 'koča, bajta');

\begin{tabular}{|l|l|l|l|}
\hline Pri Bajtnjaku & \multicolumn{1}{|c|}{ Gospodar } & \multicolumn{1}{|c|}{ Kraj } & \multicolumn{1}{c|}{ Zgodovinski zapis } \\
\hline Par Bájtnjeko & Bájtnjek & $\begin{array}{l}\text { Srednja vas } \\
\text { v Bohinju }\end{array}$ & FK 1827: Baitnek, SA 1821: Bajtnek \\
\hline
\end{tabular}

pri bajtnjaku $<*$ pri 'pri' $+*($ bajt)bńak-b $(\leftarrow *$ (bajt) $-a \leftarrow$ ben. it. baita, furl. baite 'koča, bajta');

\begin{tabular}{|c|l|l|l|}
\hline Pri Bajtnežu & \multicolumn{1}{|c|}{ Gospodar } & \multicolumn{1}{|c|}{ Kraj } & \multicolumn{1}{c|}{ Zgodovinski zapis } \\
\hline Par Bájtnəž & Bájtnəž & Moste & SA 1902: V Bajti \\
\hline
\end{tabular}

pri bajtnežu $<*$ pri 'pri' + *(bajt)-bn-ež-b ( $\leftarrow$ ben. it. baita, furl. baite 'koča, bajta').

\section{Hišna imena, tvorjena iz apelativa kajža $^{16}$}

Besedotvorno bolj raznolika so poimenovanja, tvorjena iz apelativa kajža. Le enkrat se ta apelativ kot lastno ime pojavlja v imenovalniku ednine (Kajža), sicer pa so hišna imena predvsem besedne zveze. Pogoste so besedne zveze iz levega pridevniškega prilastka, ki označuje (nekdanjega) lastnika, in apelativa kajža v jedru samostalniške besedne zveze. Pridevniški prilastek je navadno tvorjen s svojilno pripono $-o v-a$

${ }^{16}$ SSKJ: $\boldsymbol{k a j z ̌ a ~ ' m a j h n a , ~ p r e p r o s t a ~ h i s ̌ a ' . ~}$ 


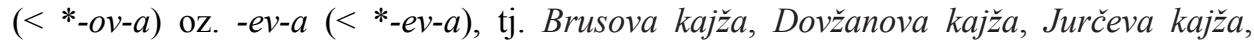
Krvinova kajža, Kušpergarjeva kajža, Lenartova kajža, Magušarjeva kajža, Mulejeva kajža, Murnčeva kajža, Oštrmanova kajža, Pičmanova kajža, Podršnikova kajža, Pstotarjeva kajža. Apelativ v mestniku ednine pa je lahko del imena v obliki predložne zveze s predlogom $v$ (V Kajži) ali, redkeje, pri (Pri Kajži).

Večina hišnih imen, tvorjenih iz apelativa kajža, so predložne zveze s predlogom pri in tvorjenko, ki poimenuje lastnika oz. prebivalca kajže. Izpeljanke so tvorjene s priponami -ar $\left(<*_{-} a \dot{r}^{-} b\right),-n i k\left(<*_{-} b n-i k-b\right),-n j a k\left(*_{-}-b n^{\prime}-a k-b\right),-e c\left(<*_{-b c-b}\right),-o v-e c$

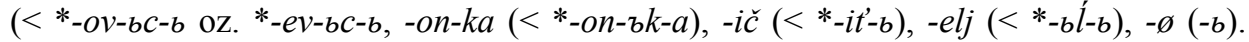

\begin{tabular}{|l|l|l|l|}
\hline Pri Kajžarju & \multicolumn{1}{|c|}{ Gospodar } & \multicolumn{1}{c|}{ Kraj } & \multicolumn{1}{c|}{ Zgodovinski zapis } \\
\hline Pər Kájžarja & Kájžar & Babni Vrt & SA 1880, 1900: Kajžar \\
\hline Pər Kájžarjə & Kájžar & Kovor & RK 1867: Kajžar, SA 1768-1859: Kajshar \\
\hline Pər Kájžarjo & Kájžar & Podjelje & FK 1827: Kaischar, SA 1891: Kajshar, 1882: Kajžar \\
\hline
\end{tabular}

pri kajžarju $<*$ pri 'pri' $+*(k a j z ̌)-a r ́-b\left(\leftarrow{ }^{*}[k a j z ̌]-a \leftarrow\right.$ bav. nem. Kaische, Keische 'kajža, koča' [pred prehodom $* \check{z}>\check{s}]$ ).

Izglasna $-\curvearrowright$ in - $o$ sta se razvila po oslabitvi nenaglašene končnice $-u$.

\begin{tabular}{|l|l|l|l|}
\hline Pri Kajžniku ${ }^{18}$ & \multicolumn{1}{|c|}{ Gospodar } & \multicolumn{1}{c|}{ Kraj } & \multicolumn{1}{c|}{ Zgodovinski zapis } \\
\hline Pər Kájžznk & Kájžənk & Rateče & FK 1827: Kaishenk, SA 1846: Kaishnik \\
\hline Par Kájžənk & Kájžnek & Javorniški Rovt & RK 1868: Kajžnek \\
\hline Pər Kájžənk & Kájžənk & Zgornja Besnica & SA 1785-1894, 1793-1901: Kaižnik \\
\hline Pər Kájžneko & Kájžnek & Mevkuž & $\begin{array}{l}\text { FK 1827: Kaischouz, SA 1790-1905: Kajžnjek, } \\
\text { 1900: Kajžnik }\end{array}$ \\
\hline Par Kájžnek & Kájžnek & Skaručna & SA 1774-1870: Žepančeva kajža \\
\hline
\end{tabular}

pri kajžniku $<*$ pri 'pri' $+*(k a j z ̌)-b n-i k-ъ\left(\leftarrow{ }^{*}[k a j z ̌]-a \leftarrow\right.$ bav. nem. Kaische, Ke-

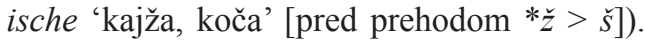

Pripona $-n i k$ se je zaradi narečne samoglasniške oslabitve ponaglasnega $-i-\mathrm{v}$ tej priponi razvila $\mathrm{v}-n e k$ ali -ənk.

\begin{tabular}{|l|l|l|l|}
\hline \multicolumn{1}{|c|}{ Pri Kajžnjak } & \multicolumn{1}{|c|}{ Gospodar } & \multicolumn{1}{c|}{ Kraj } & \multicolumn{1}{c|}{ Zgodovinski zapis } \\
\hline Pər Kájžnjeko & Kájžnjek & Srednji Vrh & FK 1827: Kaisnek \\
\hline
\end{tabular}

pri kajžnjaku $<*$ pri 'pri' $+*(k a j z ̌)-b n ́-a k-\mathrm{b}\left(\leftarrow{ }^{*}[k a j z ̌]-a \leftarrow\right.$ bav. nem. Kaische, Keische 'kajža, koča' [pred prehodom $* \check{z}>\check{s}]$ ).

\footnotetext{
${ }^{17}$ Naveden je le del gradiva - na Gorenjskem je doslej zabeleženih 19 hišnih imen Pri Kajžarju.

${ }^{18}$ Naveden je le del gradiva - na Gorenjskem je doslej zabeleženih 13 hišnih imen Pri Kajžniku/PriKajžneku/Kajženku.
} 


\begin{tabular}{|c|l|l|l|}
\hline \multicolumn{1}{|c|}{ Pri Kajžcu } & \multicolumn{1}{|c|}{ Gospodar } & \multicolumn{1}{c|}{ Kraj } & \multicolumn{1}{c|}{ Zgodovinski zapis } \\
\hline Par Kájšcu & Káǰ̌s & Praproše & SA 1795-1889: Bajtar \\
\hline
\end{tabular}

pri kajžcu < *pri 'pri' +*(kajž)-bc-b $(\leftarrow *$ [kajž] $-a \leftarrow$ bav. nem. Kaische, Keische 'kajža, koča' [pred prehodom *ž > š] ).

\begin{tabular}{|l|l|l|l|}
\hline Pri Kajževcu & \multicolumn{1}{|c|}{ Gospodar } & \multicolumn{1}{|c|}{ Kraj } & \multicolumn{1}{c|}{ Zgodovinski zapis } \\
\hline Par Kájžovc & Kájžovc & $\begin{array}{l}\text { Begunje na } \\
\text { Gorenjskem }\end{array}$ & SA 1750-1859: Kajskouz, SA 1750-1873: Kajskovz \\
\hline Par Kájžovc & Kájžovc & Breg o Kokri & $\begin{array}{l}\text { FK 1827: Kaishoutz, SA 1771: Kaishouz, SA 1880: } \\
\text { Kajžovec }\end{array}$ \\
\hline Par Kájžovco & Kájžovc & Breg o Kokri & SA 1891: Grabnar Kajshouz, SA 1882: Kajžovc \\
\hline
\end{tabular}

pri kajževcu $<*$ pri 'pri' $+*(k a j z ̌)-e v-b c-b(\leftarrow *[k a j z ̌]-a \leftarrow$ bav. nem. Kaische, Keische 'kajža, koča' [pred prehodom $* \check{z}>\check{s}]$ ]).

Pridevnik iz hišnega imena je lahko Kájžov (npr. Nova vas pri Lescah) ali Kájžovčov (npr. Jereka).

\begin{tabular}{|c|l|l|l|}
\hline Pri Kajžiču & \multicolumn{1}{|c|}{ Gospodar } & \multicolumn{1}{c|}{ Kraj } & \multicolumn{1}{c|}{ Zgodovinski zapis } \\
\hline Par Káǰ̌č & Káǰ̌č & $\begin{array}{l}\text { Begunje na } \\
\text { Gorenjskem }\end{array}$ & $\begin{array}{l}\text { SA 1750-1859: Kovazhiova Kaisha, SA 1750-1873: } \\
\text { Kovazhjova Kajsha }\end{array}$ \\
\hline
\end{tabular}

pri kajžiču $<*$ pri 'pri' $+*(k a j z ̌)-i t '-b(\leftarrow *[k a j \check{z}]-a \leftarrow$ bav. nem. Kaische, Keische 'kajža, koča' [pred prehodom $* \check{z}>\check{s}$ ] $)$.

\begin{tabular}{|l|l|l|l|}
\hline Pri Kajželjnu & \multicolumn{1}{|c|}{ Gospodar } & \multicolumn{1}{c|}{ Kraj } & \multicolumn{1}{c|}{ Zgodovinski zapis } \\
\hline Par Kájžzlno & Kájžəl & Potoki & FK 1826: Kaischel \\
\hline
\end{tabular}

pri kajželjnu $<*$ pri 'pri' $+*(k a j z ̌)-b l-b(\leftarrow *[k a j z ̌]-a \leftarrow$ bav. nem. Kaische, Keische 'kajža, koča' [pred prehodom *ž > š]).

Osnova, ki se končuje na (sicer depalatalizirani) -lj- se podaljšuje z - $n$-.

\begin{tabular}{|l|l|l|l|}
\hline \multicolumn{1}{|c|}{ Pri Kajžu ${ }^{20}$} & \multicolumn{1}{|c|}{ Gospodar } & \multicolumn{1}{c|}{ Kraj } & \multicolumn{1}{c|}{ Zgodovinski zapis } \\
\hline Par Kájžo & Kájž & Bled - Rečica & FK 1827: Kaisoutz, SA 1830: V Kaishi \\
\hline Par Kájžo & Kájž & $\begin{array}{l}\text { Gozd } \\
\text { Martuljek }\end{array}$ & FK 1827: Kaischouz, SA 1903: Kajžen \\
\hline Par Kájžo & Kájžovc & Nemški Rovt & FK 1827: Kaisouz, SA 1921: Kajžar \\
\hline Par Kájž & Kájž & Brezje & / \\
\hline
\end{tabular}

pri kajžu $<*$ pri 'pri' $+*(k a j z ̌)-b(\leftarrow *[k a j z ̌]-a \leftarrow$ bav. nem. Kaische, Keische 'kajža, koča' [pred prehodom $* \check{z}>\check{s}])$.

${ }^{19}$ Naveden je le del gradiva - na Gorenjskem je doslej zabeleženih 7 hišnih imen Pri Kajžovcu, brez preglasa $-o-v-e$ - za palatali.

${ }^{20}$ Naveden je le del gradiva - na Gorenjskem je doslej zabeleženih 19 hišnih imen Pri Kajžu. 


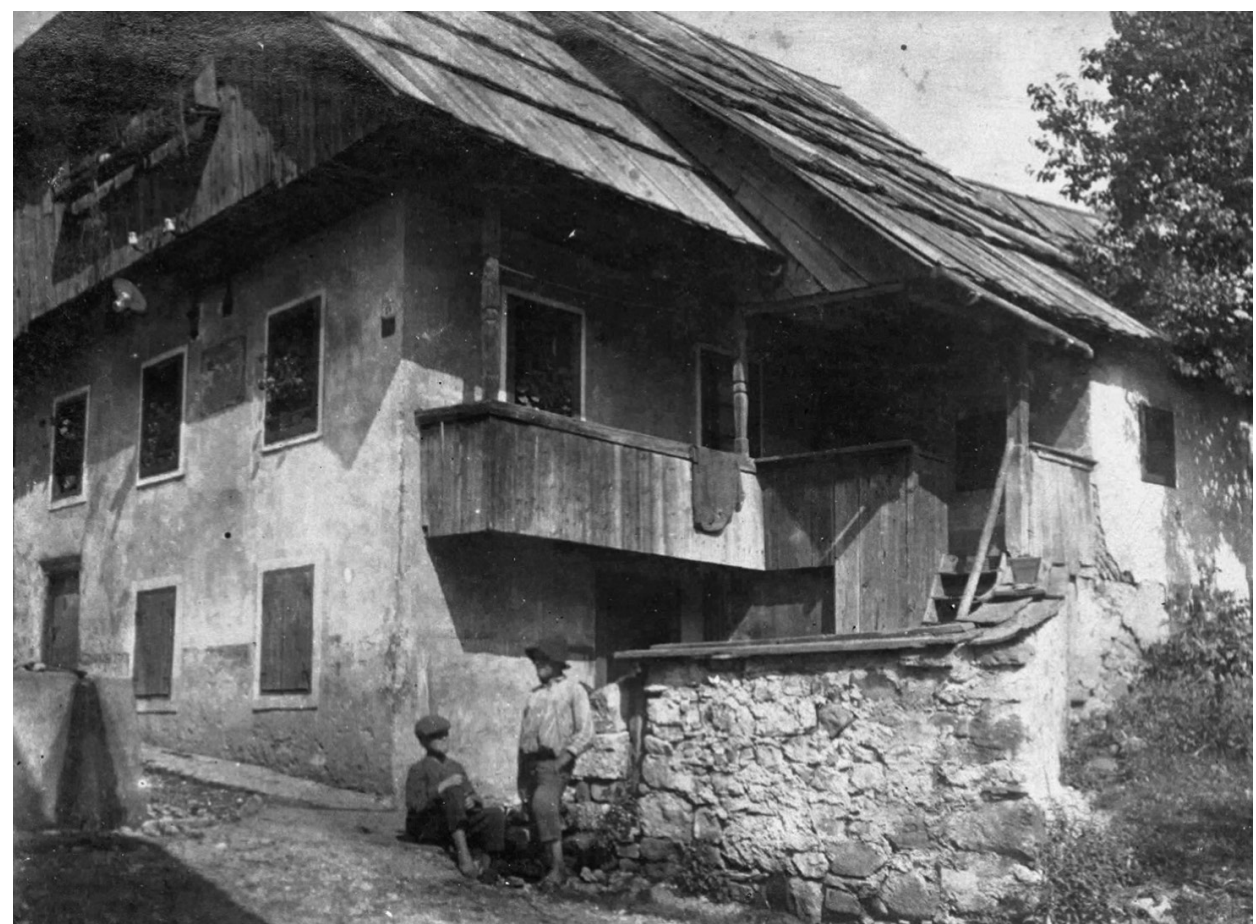

Il. 6. Pri Kajžu na Hrušici (vir: dokumentacija Slovenskega etnografskega muzeja; avtor: Rado Kregar)

\begin{tabular}{|c|l|l|l|}
\hline Pri Kajžonki & \multicolumn{1}{|c|}{ Gospodar } & \multicolumn{1}{c|}{ Kraj } & \multicolumn{1}{c|}{ Zgodovinski zapis } \\
\hline Par Kajžónke & Kajžónka & $\begin{array}{l}\text { Gozd } \\
\text { Martuljek }\end{array}$ & SA 1903: Robičeva \\
\hline
\end{tabular}

pri kajžonki < *pri 'pri' $+*$ (kajž)-on-ъk-a $(\leftarrow *$ [kajž]-a $\leftarrow$ bav. nem. Kaische, Keische 'kajža, koča' [pred prehodom $\left.\left.*_{z ̌}>\check{s}\right]\right)$.

\section{Hišna imena, tvorjena iz apelativa gost $t^{22}$}

Redko se kot hišna imena na Gorenjskem pojavljajo druga poimenovanja kmečkih posestnikov ali najemnikov. Sem je mogoče uvrstiti hišna imena s korenom gost, tj. gostač in gostak

${ }^{21}$ To ime naj bi bilo motivirano z vzdevkom gospodinje, ki se je na domačijo primožila iz kajže. V knjigi domačina Stanka Koširja $V$ coklah na pot, 2008, je ime zapisano s palatalizacijo $-k$ - $v-c ̌-$ pred končnico $-i$, ki je oslabela v -e, tj. Pr'Kajžončé.

${ }^{22}$ SSKJ: gost 'kdor se [kje] začasno mudi, stanuje'. 


\begin{tabular}{|l|l|l|l|}
\hline Pri Gostaču & \multicolumn{1}{|c|}{ Gospodar } & \multicolumn{1}{|c|}{ Kraj } & \multicolumn{1}{c|}{ Zgodovinski zapis } \\
\hline Par Gustáč & Gustàč & Križ & SA 1843: Goshtazh, SA 1903: Gostač \\
\hline Par Gostk̀̀ & Gostàk & Breg ob Kokri & FK 1827: Gosdek, SA 1771, 1880: Gostek \\
\hline Par Gustkà & Gustàk & Zgornje Pirniče & SA 1795-1900: Gostek \\
\hline
\end{tabular}

pri gostaču < *pri 'pri' + *gost-ač-b $\left(\leftarrow{ }^{*}\right.$ gost-b 'gost');

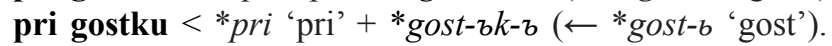

Hišna imena, tvorjena iz apelativa hlev $^{23}$

\begin{tabular}{|l|l|l|l|}
\hline Pri Hlevarju & \multicolumn{1}{|c|}{ Gospodar } & \multicolumn{1}{c|}{ Kraj } & \multicolumn{1}{c|}{ Zgodovinski zapis } \\
\hline Pər Hlévarja & Hlévar & $\begin{array}{l}\text { Bohinjska } \\
\text { Bela }\end{array}$ & SA 1900-1910: Hlevar \\
\hline Pər Hlévarja & Hlévar & Ljubno & $/$ \\
\hline Par Hlévarja & Hlévar & Šenčur & FK 1827: Hlevar \\
\hline Pər Hlévari & Hlévar & Podlonk & SA 1850-1960: Hlevar \\
\hline
\end{tabular}

pri hlevarju $<{ }^{*}$ pri 'pri' $+{ }^{*} x l e \check{v}$ - $a \dot{r}-b \leftarrow{ }^{*} x l e ̌ v-b$ 'hlev, staja'.

\section{Sklep}

$\mathrm{Na}$ Gorenjskem so hišna imena pogosto motivirana tudi z občnimi imeni/apelativi za velike in manjše kmečke posestnike - kmeta (kmet, gruntar, paver), gruntarja (kmet, velik kmet, kmetavzar ter gruntar, velik gruntar in velik paver) in bajtarja (bajtar, kajžar, kajžljar, majhen kmet, gostač, hlevar). V raziskavi so hišna imena s temi apelativi (prikazanimi tudi na jezikovnih kartah) predstavljena predvsem s stališča tvorjenosti (večinoma gre za besedne zveze iz predloga in samostalnika ali samostalniške besedne zveze), opozorjeno pa je tudi na v njih izkazane glasoslovne narečne značilnosti. Hišna imena izkazujejo precej večjo tvorbno/izpeljavno raznolikost kot danes živi narečni apelativi, v katerih besedno družino jih je mogoče uvrstiti (kmet in kmetič, bajtar, bajtni, bajtnik, bajtnjak in bajtnež, kajžar, kajžnik, kajžnjak, kajžec, kajževec, kajžič, kajželj, kajž in kajžonka, gostač in gostek). Raziskovanje hišnih imen torej omogoča tako poglabljanje glasovnorazvojnih raziskav narečij kot tudi raziskave s področja narečnega besedotvorja in so zato dragocen vir ne le za onomastiko, ampak tudi za dialektologijo.

${ }^{23}$ SSKJ: hlev 'stavba, prostor za bivanje domačih živali, zlasti večjih'. 


\section{Literatura}

Baš A. (1980), Slovensko ljudsko izročilo, Ljubljana.

Baš F. (1984), Stavbe in gospodarstvo na slovenskem podeželju: izbrani etnološki spisi, Ljubljana. Baš A. (2004), Slovenski etnološki leksikon, Ljubljana.

Benedik F. (1999), Vodnik po zbirki narečnega gradiva za Slovenski lingvistični atlas (SLA), Ljubljana.

Čop D. (1983), Imenoslovje Zgornjesavskih dolin, disertacija, Ljubljana.

Klinar K., Škofic J., Šekli M., Piko-Rustia M. (2012), Metode zbiranja hišnih in ledinskih imen: projekt FLU-LED v okviru Operativnega programa Slovenija-Avstrija 2007-2013, Jesenice.

Logar T. (1981), Govor Repenj - Kopitarjevega rojstnega kraja, „Seminar slovenskega jezika, literature in kulture", zv. 17, str. 129-141 [ponatis v: Logar T. (1996), Dialektološke in jezikovnozgodovinske razprave, ur. K. Kenda-Jež, Ljubljana, str. 173-179].

Sedej I. (1983), Kmečki dvorci na Slovenskem, „Varstvo spomenikov”, št. 25.

Sedej I. (1989), Sto najlepših kmečkih hiš na Slovenskem, Ljubljana.

Snoj M. (2009), Etimološki slovar slovenskih zemljepisnih imen, Ljubljana.

Sławski F. (1974-1979), Zarys słowotwórstwa prastowiańskiego, [v:] Słownik prasłowiański, t. I: $A-B, 1974$, str. 43-141; t. II: C-davbnota, 1976, str. 13-60; t. III: davbnb-dobbrati, 1979, str. 11-19, Wrocław-Warszawa-Kraków-Gdańsk.

Striedter-Temps H. (1963), Deutsche Lehnwörter im Slovenischen, Berlin.

Škofic J. et al. (2011), Slovenski lingvistični atlas, zv. 1: Človek (telo, bolezni, družina), d. 1: Atlas, d. 2: Komentarji, Ljubljana.

Škofic J. et al. (2016), Slovenski lingvistični atlas, zv. 2: Kmetija, d. 1: Atlas, d. 2: Komentarji, Ljubljana.

\section{Viri}

Gradivo za Slovenski lingvistični atlas. Arhiv Dialektološke sekcije Inštituta za slovenski jezik Frana Ramovša ZRC SAZU v Ljubljani.

\section{Spletni viri}

FLU-LED, Kulturni portal ledinskih in hišnih imen / Kulturportal der Flur- und Hausnamen, http://fluled.szi.at/, 14.02.2020.

Fran, slovarji Inštituta za slovenski jezik Frana Ramovša ZRC SAZU, 2014-, različica 6.0, www.fran.si, 14.02.2020.

Hišna imena na Gorenjskem, https://www.hisnaimena.si/, 28.02.2021.

Digitalne zbirke Slovenskega etnografskega muzeja, https://www.etno-muzej.si/s1/digitalne-zbirke, 28.02.2021. 